$\stackrel{W}{=}$

Global burnals Inc.

है

\title{
Human Immunodeficiency Virus Infectious Profile Change in Mali: A Narrative Review
}

\author{
By Nouhoum Bouare, Sebastien Bontems \& Christiane Gerard
} Abstract- West Africa is reputed as an epicenter of HIV-2 infection. Studies undertaken in Mali suspected HIV-1 more prevalent. Our study aims to document HIV infectious profiles in Mali and analyze HIV-1 dominance. We documented HIV studies undertaken in Mali from 1985 to 2010. We proceeded to a bibliographic search focused on theses from the Medicine Pharmacy Odontostomatology Faculty (FMPOS) of Bamako, survey reports, and abstracts or papers published in reviews with the reading committee. Documents were physically and virtually (via website) consulted and exploited. We gave preference to studies that discriminated against HIV serotypes. The data were analyzed according to study population/publication, representativeness, infectious profiles reporting, socio-demographic and clinical characteristics. HIV profiles variation in space and time was analyzed by using a linear regression model. Calculations were done using Excel software.

Keywords: epidemiology, HIV infection, serotypes change, Mali, West Africa.

\section{GJMR-C Classification: NLMC Code: QW 501}

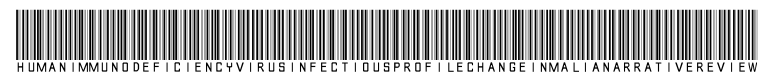

Strictly as per the compliance and regulations of:

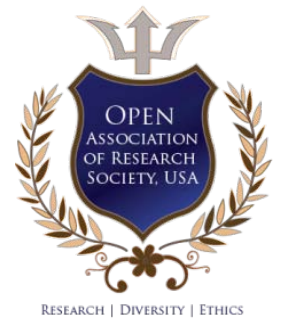

(C) 2021. Nouhoum Bouare, Sebastien Bontems \& Christiane Gerard. This research/review article is distributed under the terms of the Attribution-NonCommercial-NoDerivatives 4.0 International (CC BY-NC-ND 4.0). You must give appropriate credit to authors and reference this article if parts of the article are reproduced in any manner. Applicable licensing terms are at https://creativecommons.org/licenses/by-nc-nd/4.0/. 


\title{
Human Immunodeficiency Virus Infectious Profile Change in Mali: A Narrative Review
}

\author{
Nouhoum Bouare ${ }^{\alpha}$, Sebastien Bontems ${ }^{\sigma}$ \& Christiane Gerard $^{\circ}$
}

Abstract- West Africa is reputed as an epicenter of HIV-2 infection. Studies undertaken in Mali suspected HIV-1 more prevalent. Our study aims to document HIV infectious profiles in Mali and analyze HIV-1 dominance. We documented HIV studies undertaken in Mali from 1985 to 2010 . We proceeded to a bibliographic search focused on theses from the Medicine Pharmacy Odontostomatology Faculty (FMPOS) of Bamako, survey reports, and abstracts or papers published in reviews with the reading committee. Documents were physically and virtually (via website) consulted and exploited. We gave preference to studies that discriminated against HIV serotypes. The data were analyzed according to study population/publication, representativeness, infectious profiles reporting, socio-demographic and clinical characteristics. HIV profiles variation in space and time was analyzed by using a linear regression model. Calculations were done using Excel software. Out of 17 studies that reported HIV profiles, nine documented in full serotypes profiles. They mainly concerned health care patients and prostitutes, as they are likely more exposed to HIV infection. The sexual route was mostly described. In prostitutes group, significant regression of HIV-2 was observed between 1987-1989 and 1995 (65/517 vs 7/176) $(p=0.001)$ while HIV-1 increased (36/517 vs. 63/176) ( $p$ $<0.0001)$. The chronology of events showed prior existence of both profiles but with an initial dominance of HIV-2. The study surprisingly highlighted HIV-1 profile dominance in Mali, whereas West Africa is reputed as an HIV-2 epicenter. However, it suffered lack of representativeness of preliminary studies. HIV profile change and propagation seem essential due to the sexual route in this country.

Keywords: epidemiology, HIV infection, serotypes change, Mali, West Africa.

\section{INTRODUCTION}

W /est Africa is reputed to be the epicenter of HIV2 infection [1]. This HIV profile was also endemic in the same geographic area [2]. In Mali, the first AIDS case was identified in 1985 [3]. In this country, the early studies reported a dominance of HIV-2 on HIV-1 [4, 5, 6, 7]. However, an anterior study conducted in patients admitted in pneumophtisiology setting revealed HIV-1 more prevalent in the sub-study population of non-tuberculosis patients [8]. Unlike the

Corresponding Author a: $P h D$, Department of Biomedical Research of National Public Health Institute (INSP/ former INRSP) of Bamako, Mali. e-mail: nouhoumsamakoro@yahoo.fr

Author $\sigma:$ PhD, Department of Clinical Microbiology of University Hospital, Liege Belgium.

Author p: PhD, Former Responsible of Blood Bank of University Hospital, Liege Belgium. prior studies, more or less recent works conducted in this country reported an opposite trend [9-20]. However, in the country, a significant higher HIV-2 prevalence was observed in 2010 in older women than in young ones (in 2009), despite a high HIV-1 dominance in the both populations [19]. This HIV-2 trend in older adults contrasting with the low trend in young ones, aroused our curiosity to analyze the dominance of the HIV-1 infectious profile that seems plausible in Mali.

\section{il. Methodology}

\section{a) Procedure}

This narrative review consisted of analyzing the data from preview studies concerning HIV infection in Mali. We have pursued a bibliographic search focused on HIV studies (subject or not to publication in scientific reviews) undertaken in Mali from 1985 to 2010. The FMPOS theses file, as well as papers related to HIV/AIDS topic, were consulted and exploited for data collection and analysis. We prioritized studies having documented the serotypes profiles (HIV-1, HIV-2, and HIV-1/2), by using a discriminatory or confirmatory test. We structured the argumentation around the following criteria: study period, publication date and reference; study population including hospital patients, prostitutes, pregnant women, blood donors, general population; study sample size; study population characteristics such as ages, average age, gender, underlying diseases, clinical symptoms, risk factors; stratification by age (<50-years-old and >50-years-old); testing for HIV serotypes profiles discrimination using immunochromatography, Western Blot or Line Immunoassay principle; typology of the publication such as abstracts or full text from international journals, meetings or conferences presentations, theses and reports.

\section{b) Statistical Analysis}

Results are presented as mean \pm SD (range) for continuous variables and frequencies (\%) for categorical variables. Categorical variables were compared between the groups using a chi-square test. Results were significant at the $5 \%$ level $(p<0.05)$. Linear Regression model was used to analyze the HIV profiles trends. Calculations were done using Excel Software. 


\section{c) Human Subjects}

This proposed study uses an anonymous secondary data set, and does not qualify as human subject research.

\section{Results}

A total of 17 studies were exploited. They mainly concerned health care patients and prostitute women populations (Table 1), as they are likely to be more exposed to HIV infection than the general population. Samples size in these studies ranged from 23 to 3179 subjects (Table 2). Regarding the stratification of population by age ( $<50$-years-old versus $>50$-yearsold), a study revealed that despite HIV-1 prevalence was high in both strata, HIV-2 was significantly more prevalent in the older populations than in younger (2/1000 vs. $5 / 231)$ ( $p=0.0003)$. Out of 17 studies reviewed nine only documented in full HIV serotype profiles from the abstract and/or full text (Table 2). This table also informs on HIV prevalence that ranges between $0.73 \%$ and $75.79 \%$. The lowest prevalences were observed in blood donors and pregnant women. The prostitutes and health care patients were the most affected. When one considers only the prostitutes populations (Table 2), a significant regression of HIV-2 can be observed between 1987-1989 and 1995 (65/517 vs. $7 / 176)$ ( $p=0.001)$. Conversely, HIV-1 increased significantly during the same period (36/517 vs. 63/176) $(p<0.0001)$. As far as health care patients are only concerned, there was a significant increase in HIV-1 $\left(Y_{\text {HV }-1}=9.20 \mathrm{x}+22.80 ; \mathrm{R}^{2}=0.6351\right)$ while HIV-2 significantly regressed $\left(\mathrm{Y}_{\mathrm{HIV}-2}=-3.81 \mathrm{x}+34.47 ; \mathrm{R}^{2}=\right.$ 0.2895). Furthermore, when taking into account the overall population, a similar trend can be observed ( $\mathrm{Y}_{\mathrm{HIV}-1}$ $\left.=8.48 \mathrm{x}+16.38 ; R^{2}=0.646\right)$ VS $\left(Y_{H I V-2}=-5.626 \mathrm{x}+\right.$ 55.82; $R^{2}=0.3321$ ). The chronology of events, as well in all the populations studied as in health care patients taken alone (Table 2 and 3; fig1 and 2), shows that both infectious profiles have pre-existed in Mali, but with an initial predominance of HIV-2 and change toward HIV-1 that occurred probably between 1990 and 1994.

\section{Discussion}

A Malian study reported a higher HIV seroprevalence in prostitutes in 1991 (70\%) [21]. In Mali, HIV prevalence of $4.1 \%(41 / 1000)$ was measured in 2009 in pregnant women (young women), with a higher dominance of HIV-1 $(95 \%)[19,22]$. This seroprevalence measured in 2009 in the Bamako district was comparable to $3.5 \%(183 / 5224)$ reported in 2006 in pregnant women recruited from seven locations (including Bamako) across the country [23]. Likewise, in 2010, HIV seroprevalence 6.1\% (14/231) measured in older women did not differ from $4.1 \%$ reported in young ones $[19,22]$. By contrast, the proportion of HIV-2 was significantly higher in older women than in younger ones, $2.16 \%$ (5/231) vs. $0.2 \%$ (2/1000); $p<0.001$. The HIV epidemiological profile between 1985 and 2010 shows at the beginning of this observation period HIV-2 dominance; a trend that has been reversed later in favor of HIV-1, which is still dominant today. Indeed, several studies have revealed the dominance of HIV-1 between 1988 and 2010 [9-20], unlike the first studies undertaken in Mali between 1985 and 1989 [4, 5, 6, 7]. This new trend in favor of HIV-1 dominance contrasts a priori with evidence that West Africa is the epicenter of the epidemiology of HIV-2 [1]. Our work is limited by the lack of representativeness from some preliminary studies undertaken and reported in Mali. It suffered equally from the data insufficiency related to HIV infectious profiles in some documents consulted. Guinea-Bissau (a West African country) is described as the epicenter of the HIV-2 epidemic [24]. In the same country, HIV-1, HIV-2 and HIV-1/2 seroprevalence were respectively $1.1 \%, 8.4 \%$ and $0.1 \%$ for the period of $1992-$ 1995 and $7.7 \%, 5.1 \%$ and $1.9 \%$ in 2005 [25]. Between February 1987 and May 1988, the Central Hospital of Dakar registered HIV-1 frequency comparable to that of HIV-2 46\% (50/109) vs 40\% (44/109); p> 0.05 [26]. In the same city, prevalence rates for HIV-1 (6\%), HIV-2 (3.6\%) and HIV-1/2 (0.4\%) were reported, in 2000, among sex workers [27]. In Ivory Coast, a predominance of HIV-1 was reported in 1988 [28]. In Mali, a prior study carried out in patients enrolled in a specialized hospital reported in none tuberculosis patients a rate of $5.5 \%(9 / 164)$ for HIV-1 vs. $1.22 \%$ $(2 / 164)$ and $1.83 \%(3 / 164)$ respectively for HIV-2 and HIV-1/2 [8]. However, considering the totality of patients with or without tuberculosis, the frequencies were $4.58 \%$ $(22 / 480), 2.71 \% \quad(13 / 480)$, and $3.96 \%$ (19/480), respectively for HIV-1, HIV-2, and HIV-1/2. In this country, a high frequency of HIV-1 was reported in 2009 among students [20]. Bouare et al. demonstrated that HIV-2 was significantly more common in older women than in younger ones [19]. Suggesting HIV-2 infection occurred earlier (probably 20 years or more) in these older adults infected. That may explain and confirm two hypotheses: HIV-2 infection oldness and HIV infectious profile change toward HIV-1 in Mali. Moreover, from 1988 to 1992, we observe a quantitative dominance of HIV-1 2.99\% (71/2378) vs. 0.97\% (23/2378) and 1.39\% (33/2378) respectively for HIV-2 and HIV-1/2 [9]. A study conducted between 1990 and 1999 even reported a predominance of HIV-1 with a prevalence of $58.55 \%$ (462/789) vs. $5.58 \%(44 / 789)$ and $11.66 \%$ (92/789) respectively for HIV-2 and HIV $-1 / 2$ [10]. It also described the growing trend of emigration between 1993 and 1998 (4.18\% to 8.11\%), a sexual transmission rate of $98.10 \%$, the first peak of HIV-1 in 1992, and persistent latency observed for HIV-2. This rate of $98.10 \%$ of sexual transmission is supported by Bouare et al. [22], who reported that HIV transmission might be essentially sexual in Mali. The data for the study 
between 1987 and 1989 [6, 7] attributed a significant proportion of HIV infection linked to staying (since 1980) in Central Africa, West Africa, and Europe. This could partially explain the foreign exposition and contamination of the people before they come back in Mali. Other studies in Mali focused on prostitution which can explain the spread of HIV infection [4, 5, 6, 13, 14, 21]. One of them reported that the highest prevalence was $70 \%$ among registered prostitutes in 1991, and most regions of Mali had experienced higher HIV prevalence among sex workers in 1992 compared to 1988 [21]. Also, a bibliographical study of the period 1983 to 2003 reported in 2004 the dominance of HIV-1 since 1990 and HIV-2 dominance before that time [14]. It also pointed out limitations such as poor access to studies, especially that of NGOs (Non-Governmental Organizations), and insufficient data regarding some summaries in general. Through a study conducted in 1995 in Mali regarding prostitutes mainly composed of foreign (including Nigerian and Ghanaian), Peeters and coworkers reported a significant increase in HIV-1 against a decrease of HIV-2 [13]. They also reported the similarity of this trend with those observed in the neighboring countries of Mali. They hypothesized recent contamination among women who started sex work a year (or less than a year) before they conducted their study since HIV-1 subtype G was detected. As for our study, when we consider only the population of prostitute women, significant regression of HIV -2 is observed between the periods 1987 to 1989 and 1995 [12.57 \% (65/517) vs. 3.98\% (7/176)]; $p=0.001$. Conversely, HIV-1 increased significantly during the same period [6.96\% (36/517) vs. 35.79\% (63/176)]; $p<$ 0.0001 . This is further corroborated and confirmed by the linear regression analysis related HIV infectious profile change in the both patient population $\left(\mathrm{Y}_{\mathrm{HIV}-1}=\right.$ $9.20 \mathrm{x}+22.80, R^{2}=0.6351 ; Y_{\text {HIV-2 }}=-3.83 x+34.47, R^{2}$ $=0.2895)$ and all the combined populations $\left(Y_{\text {HV }-1}=\right.$ 8.48x $+16.38, R^{2}=0.6459 ; Y_{\text {HIV-2 }}=-5.626 x+55.82, R^{2}$ $=0.3321$ ). From the above, we suggest that the reversal of the epidemiological profile of HIV for HIV-1 probably occurred in Mali between 1990 and 1994, while Antonio Biague et al. described the HIV-1 increase and HIV-2 decline between 1992-1995 and 2005 [25]. In HIV epidemiological study context, documenting of all serotypes profiles (HIV-1, HIV-2, and HIV-1/2) and genotypes in both abstract statement and full text (usually difficult to access) are needed to track their evolution in space and time and enable more precise dating of infectious profiles to change.

In conclusion, this present work surprisingly highlighted HIV-1 profile predominance in Mali, whereas West Africa is reputed to be the HIV-2 epicenter. The HIV profile change seems to occur between 1990 and 1994. The transmission risks and routes such as sexual, trip duration and emigration are a fortiori highlighted. The propagation of HIV infection seems essentially linked to the sexual route in this country.

\section{References Références Referencias}

1. Santiago ML, Range $F$, Keele BF et al. Simian immunodeficiency virus infection in free-ranging sooty mangabeys (Cercocebus atys atys) from the Taï Forest, Côte d'Ivoire: implications for the origin of epidemic human immunodeficiency virus type 2 . J Virol. 2005; 79(19):12515-27

2. Ekouevi DK, Balestre E, Coffie PA et al. Characteristics of HIV-2 and HIV-1/HIV-2 Dually Seropositive Adults in West Africa Presenting for Care and Antiretroviral Therapy: The leDEA-West Africa HIV-2 Cohort Study. PLoS One. 2013; 8(6): e66135

3. Ballo MB, Traore SM, Niambele I et al. Enquête Démographique et de Santé (EDS-M III) 2001. Available from: URL: http://www.dhsprogram.com/ pubs/pdf/FR134/FR134-ML01.pdf

4. Pichard E, Guindo A, Grossetete $G$ et al. Human immunodeficiency virus (HIV) infection in Mali. Med Trop. 1988; 48(4):345-349. Available from: URL: http://europepmc.org/abstract/med/3221782

5. Traoré Salimata. Contribution à l'étude de la séroconversion anti-HIV du Sida chez les groupes à risque à Bamako. Thèse Pharmacie ENMP Bamako 1987; N:1987-P-2

6. Diarra Boubacar D. Contribution à l'étude de la séroprévalence de l'infection par le virus de I'Immunodéficience Humaine au Mali : à propos de 3500 sérums. Thèse Médecine ENMP Bamako 1988; N: 1988-M-19

7. Maiga MY, Diarra B, Guindo A et al. Seroprevalence of human immunodeficiency virus infection (HIV) in Mali on 3,496 sera. Bull Soc Path Ex. 1993; 86(1): 16-20 Available from: URL: http://www.pathexo.fr/ documents/articles-bull/BullSocPatholExot-1993-861-016-020.pdf

8. Basse Cheick. Contribution à l'étude de l'infection à $\mathrm{VIH}$ en milieu Hospitalier Spécialisé à Bamako à propos d'une étude prospective portant sur 480 malades hospitalisés dans le Service de Pneumophtisiologie de l'hôpital du Point G du 01 Novembre 1987 au 31 Octobre 1988. Thèse Médecine ENMP Bamako 1988; N: 1988-M-43

9. Sissoko Boubacar F. Contribution à l'étude de l'influence du type de virus sur les aspects épidémiologiques, cliniques, radiologiques et biologiques de la tuberculose associée à l'infection par le $\mathrm{VIH}$ en milieu Hospitalier Spécialisé à Bamako. Thèse Médecine ENMP Bamako 1993; N: 1993-M-1

10. Fomo Boniface. Profil Epidémiologique et Clinique des Infections et Affections au cours du VIH/SIDA dans les Services de Médecine Interne et 
d'Hémato-oncologie de l'Hôpital National du Point $G$ de Janvier 1990 à Décembre 1999. Thèse Médecine FMPOS Bamako 2001; N: 01-M-5.

11. Zakaria Soureya. Dépistage du $\mathrm{VIH}$ au Centre National de Transfusion Sanguine de Bamako de 1993 à 1999. Thèse Pharmacie FMPOS Bamako 2000-2001; N:01-P-9.

12. Coulibaly YS. Les mycoses au cours du SIDA dans deux centres hospitaliers de Bamako (l'Hôpital National du Point $G$ et le centre Hospitalier Universitaire Gabriel Touré). Thèse de Pharmacie FMPOS Bamako 2000; N: 00-P-01.

13. Peeters M, Koumare B, Mulanga $C$ et al. Genetic subtypes of HIV type 1 and HIV type 2 strains in commercial sex workers from Bamako, Mali. AIDS Res Hum Retroviruses. 1998 Jan 1;14(1): 51-8.

14. Tchalla Abalo M. ETUDE BIBLIOGRAPHIQUE SUR L'INFECTION AU VIH AU MALI : Point sur les études réalisées de 1983 à février 2003. Thèse FMPOS Bamako 2004; N: 04-P-43. Available from: URL: http//www.keneya.net/fmpos/theses/2004/pharma/p df/04P43.pdf

15. Kamsi Noutsa A. Etude épidémiologique, clinique et économique du VIH/SIDA dans le service des maladies infectieuses de l'Hôpital du Point G. A propos de 71 cas. Thèse Médecine FMPOS Bamako 2004; N:04-M-65. Available from: URL: http//www.keneya.net/fmpos/theses/2004/med/pdf/ 04M65.pdf

16. Samaké Salif, Traoré Seydou Moussa, $\mathrm{Ba}^{\dagger}$ Souleymane et al. Enquête Démographique et de Santé du Mali (EDSM-IV) 2006. Rapport Décembre 2007. Available from: URL: http//www.measuredhs. com/pubs/pdf/ FR199/FR199.pdf

17. Fofana MA. MANIFESTATIONS OPHTALMOLOGIQUES AU COURS de l'infection a vih/sida chez les enfants A PROPOS DE 81 CAS A L'I.O.T.A. Thèse FMPOS Bamako 2006; N:06M89. Available from: URL: http//www.keneya.net/fmpos/ theses/2006/med/pdf/06M89.pdf

18. Koné MC, Cissoko $Y$, Diallo $M S$ et al. Epidemiological, clinical and therapeutics' data of HIV-infected patients placed on ART in the Ségou hospital in Mali (2004-2011). Bull Soc Path Ex. 2013 Aug; 106(3): 176-9.

19. Bouare N, Vaira D, Gothot A et al. Prevalence of HIV and HCV infections in two populations of Malian women and serological assays performances. World J Hepatol. 2012; 4(12): 365-373.

20. White HL, Kristensen S, Coulibaly DM et al. Prevalence and predictors of HIV infection amongst Malian students. AIDS Care. 2009 Jun; 21(6): 701-7.

21. Doumbia Djènèba. Etude Bibliographique des Recherches Menées sur les IST/NIH au Mali de 1987 à 2000. Thèse Pharmacie FMPOS Bamako 2001; N: 01-P-48.
22. Bouare N, Gothot A, Delwaide $J$ et al. Epidemiological profiles of human immunodeficiency virus and hepatitis C virus infections in Malian women: Risk factors and relevance of disparities. World J Hepatol. 2013 April 27; 5(4): 196-205.

23. Evaluation de la co-infection VIH/VHB chez les femmes en surveillance prénatale en 2006 au Mali. Thèse FMPOS Bamako 2008; N: 08P47. Available from: URL: http//www.keneya.net/fmpos/theses/ 2008/pharma/pdf/08P47.pdf.

24. Labbé AC, Mendonça AP, Alves AC et al. The impact of syphilis, HIV-1, and HIV-2 on pregnancy outcome in Bissau, Guinea-Bissau. Sex Transm Dis. 2002 Mar; 29(3): 157-67.

25. Biague $A$, Månsson $F$, da Silva $Z$ et al. High sexual risk taking and diverging trends of HIV-1 and HIV-2 in the military of Guinea Bissau. J Infect Dev Ctries. 2010 Jun 3; 4(5): 301-8.

26. Barabe P, Digoutte JP, Tristan JF et al. Human immunodeficiency virus infections (HIV-1 and HIV-2) in Dakar. Epidemiologic and clinical aspects. Med Trop (Mars). 1988 Oct-Dec; 48(4): 337-44.

27. Laurent $\mathrm{C}$, Seck K, Coumba N et al. Prevalence of HIV and other sexually transmitted infections, and risk behaviours in unregistered sex workers in Dakar, Senegal. AIDS. 2003 Aug 15; 17(12): 1811-6.

28. Ouattara SA, Diallo D, Meite $M$ et al. Epidemiology of infections caused by human immunodeficiency viruses HIV-1 and HIV-2 in the Ivory Coast. Med Trop. 1988 Oct-Dec; 48(4): 375-9. 
Table 1: Chronology of events according to the publication date and study population characteristics

\begin{tabular}{|c|c|c|c|}
\hline Publication & \multicolumn{3}{|c|}{ Study Population Characteristics } \\
\hline Date & Population & Age (mean \pm SD) & Risk Factors and other informations \\
\hline 1987 & $\begin{array}{l}\text { Prostitutes, Prisoners, Patients, } \\
\text { Pregnant women (PW) }\end{array}$ & 26 & Prostitution, homosexuality, transfusion \\
\hline 1988 & Prostitutes & 35 & Prostitution \\
\hline 1988 & Patients & 35 & Voyage (stay at foreign) \\
\hline $1989 / 1993$ & $\begin{array}{l}\text { Prostitutes, Patients, Prisoners, } \\
\text { Women, Men }\end{array}$ & 30.18 & $\begin{array}{l}\text { Prostitution (stay at foreign), widowhood, } \\
\text { divorce, residence, tattoo, not condom use }\end{array}$ \\
\hline 1993 & Patients & & Peasants, Traders, Big travelers \\
\hline 1998 & Prostitutes & 28.8 & Prostitution \\
\hline 2000 & Patients (AIDS) & & \\
\hline 2001 & Patients & $35.19 \pm 9.45$ & $\begin{array}{l}\text { Sex transmission, emigration; first peak HIV- } \\
1 \text { (1992) and HIV-2 latency }\end{array}$ \\
\hline 2001 & Blood donors (BD) & & $\begin{array}{l}\text { Absence of discriminant test in } 93 \text { and } 99 \text {, } \\
\text { HIV-1 predominant (94-98) }\end{array}$ \\
\hline 2001 & Patients, Prostitutes, PW, BD & & Prostitution (HIV seroprevalence: $70 \%$ ) \\
\hline 2004 & Bibliographic studies of theses & & $\begin{array}{l}\text { Groups at risk: prostitutes, ambulatory } \\
\text { saleswomen, coaxers, truck drivers; lack } \\
\text { studies access, data lack in some } \\
\text { abstracts }\end{array}$ \\
\hline 2004 & Patients & $37.5 \pm 7.93$ & Stay at foreign \\
\hline 2006 & General population & & \\
\hline 2006 & Patients (children) & 7 & \\
\hline 2009 & Students & & More HIV-1 than HIV-2 \\
\hline $2012 / 2013$ & Pregnant women / Patients & $\begin{array}{c}25.2 \pm 6.3 / 62.1 \pm \\
8.6 \\
\end{array}$ & Not condom use, divorce, voyage \\
\hline 2013 & Patients & $35.2 \pm 9.4$ & $\begin{array}{l}\text { Patients (Predominantly rural, female and } \\
\text { young); Stage III WHO (64.5\%) }\end{array}$ \\
\hline
\end{tabular}

WHO: World Health Organization

Table 2: Prevalence of HIV infection according to the study period and population

\begin{tabular}{|c|c|c|c|c|c|c|c|c|}
\hline & & & $\begin{array}{c}\text { Sample } \\
\text { size }\end{array}$ & \multicolumn{3}{|c|}{ Serotypes HIV (\%)* } & HIV Frequences & P \\
\hline Date & Period & Population & $\mathrm{N}$ & HIV-1 & HIV-2 & HIV-1/2 & $\mathrm{n}(\mathrm{n} 1 ; \mathrm{n} 2 ; \mathrm{n} 1 / 2)$ & $(\%)$ \\
\hline 1987 & 1 & Prostitutes & 30 & 10,53 & 78,95 & 10,53 & $19(2 ; 15 ; 2)$ & 63,33 \\
\hline 1987 & 1 & Prisoners & 23 & 33,33 & 33,33 & 33,33 & $3(1 ; 1 ; 1)$ & 13,04 \\
\hline 1987 & 1 & Patients & 42 & 33,33 & 66,67 & 0 & $9(3 ; 6 ; 0)$ & 21,43 \\
\hline $1987-1988$ & 2 & Patients & 480 & 40,74 & 24,07 & 35,19 & $54(22 ; 13 ; 19)$ & 11,25 \\
\hline $1987-1988$ & 2 & Patients & 316 & 32,5 & 27,5 & 40 & $40(13 ; 11 ; 16)$ & 12,66 \\
\hline $1987-1988$ & 2 & Patients & 164 & 64,29 & 14,29 & 21,43 & $14(9 ; 2 ; 3)$ & 8,54 \\
\hline $1987-1989$ & 3 & Prostitutes & 487 & 27,64 & 40,65 & 31,71 & $123(34 ; 50 ; 39)$ & 25,26 \\
\hline $1987-1989$ & 3 & Prisoners & 496 & 33,33 & 55,56 & 11,11 & $18(6 ; 10 ; 2)$ & 3,63 \\
\hline $1987-1989$ & 3 & Patients & 866 & 31,4 & 46,28 & 22,31 & $121(38 ; 56 ; 27)$ & 13,97 \\
\hline $1987-1989$ & 3 & $\begin{array}{c}\text { Pregnant } \\
\text { women }\end{array}$ & 588 & 22,22 & 77,78 & 0 & $9(2 ; 7 ; 0)$ & 1,53 \\
\hline $1987-1989$ & 3 & $\begin{array}{c}\text { Blood } \\
\text { donors }\end{array}$ & 687 & 60 & 20 & 20 & $5(3 ; 1 ; 1)$ & 0,73 \\
\hline $1987-1989$ & 3 & Travellers & 372 & 47,37 & 42,11 & 10,53 & $19(9 ; 8 ; 2)$ & 5,11 \\
\hline $1987-1989$ & 3 & Women & 1578 & 25,81 & 48,92 & 25,27 & $186(48 ; 91 ; 47)$ & 11,79 \\
\hline $1987-1989$ & 3 & Men & 1903 & 40,37 & 37,61 & 22,02 & $109(44 ; 41 ; 24)$ & 5,73 \\
\hline $1987-1989$ & 3 & Housewifes & 780 & 18,75 & 64,58 & 16,67 & $48(9 ; 31 ; 8)$ & 6,15 \\
\hline
\end{tabular}




\begin{tabular}{|c|c|c|c|c|c|c|c|c|}
\hline $1987-1989$ & 3 & $\begin{array}{c}\text { People } \\
<50 \text { years } \\
\text { old }\end{array}$ & 3179 & 31,05 & 44,77 & 24,19 & $277(86 ; 124 ; 67)$ & 8,71 \\
\hline $1987-1989$ & 3 & $\begin{array}{c}\text { People } \\
>50 \text { years } \\
\text { old }\end{array}$ & 264 & 41,67 & 41,67 & 16,67 & $12(5 ; 5 ; 2)$ & 4,55 \\
\hline $1988-1992$ & 4 & Patients & 2378 & 55,91 & 18,11 & 25,98 & $127(71 ; 23 ; 33)$ & 5,34 \\
\hline $1988-1992$ & 4 & Patients & 127 & 55,91 & 18,11 & 25,98 & $127(71 ; 23 ; 33)$ & $\mathrm{N} / \mathrm{A}$ \\
\hline $1990-1999$ & 5 & Patients & 789 & 77,26 & 7,36 & 15,38 & $598(462 ; 44 ; 92)$ & 75,79 \\
\hline 1995 & 6 & Prostitutes & 176 & 77,78 & 8,64 & 13,58 & $81(63 ; 7 ; 11)$ & 46,02 \\
\hline 2003 & 7 & Patients & 71 & 87,32 & 8,45 & 4,23 & $71(62 ; 6 ; 3)$ & $\mathrm{N} / \mathrm{A}$ \\
\hline $2004-2005^{\star *}$ & 8 & Patients & 81 & 98,77 & 1,23 & 0 & $81(80 ; 1 ; 0)$ & $\mathrm{N} / \mathrm{A}$ \\
\hline $2009-2010^{* *}$ & 9 & $\begin{array}{c}\text { Pregnant } \\
\text { women }\end{array}$ & 1000 & 95,12 & 4,88 & 0 & $41(39 ; 2 ; 0)$ & 4,1 \\
\hline $2009-2010^{* *}$ & 9 & $\begin{array}{c}\text { Patient } \\
\text { women }>5\end{array}$ & 231 & 64,29 & 35,71 & 0 & $14(9 ; 5 ; 0)$ & 6,06 \\
\hline
\end{tabular}

* Data columns for figure1

**Study without HIV1/2 data (not include in figure1 data)

N/A: not applied (because study population includes HIV patients only)

$n(n 1 ; n 2 ; n 1 / 2)$ : frequencies of HIV (HIV-1; HIV-2; HIV-1/2)

$P$ : prevalence

$\%$ : percentage

\begin{tabular}{|c|c|c|c|c|}
\hline \multicolumn{2}{|c|}{ Table 3: Proportion of HIV-1, HIV-2 and HIV-1/2 infections in health care patients according to the study period } \\
\hline Date & Period & HIV-1 (\%) HIV-2 (\%) & \multicolumn{3}{c|}{ HI/2 (\%) } \\
\hline $1987-1988$ & 2 & 40,74 & 24,07 & 40,19 \\
\hline $1987-1988$ & 2 & 32,50 & 27,50 & 21,43 \\
\hline $1987-1988$ & 2 & 64,29 & 14,29 & 22,31 \\
\hline $1987-1989$ & 3 & 31,40 & 46,28 & 25,98 \\
\hline $1988-1992$ & 4 & 55,91 & 18,11 & 15,38 \\
\hline $1990-1999$ & 5 & 77,26 & 7,36 & 4,23 \\
\hline
\end{tabular}




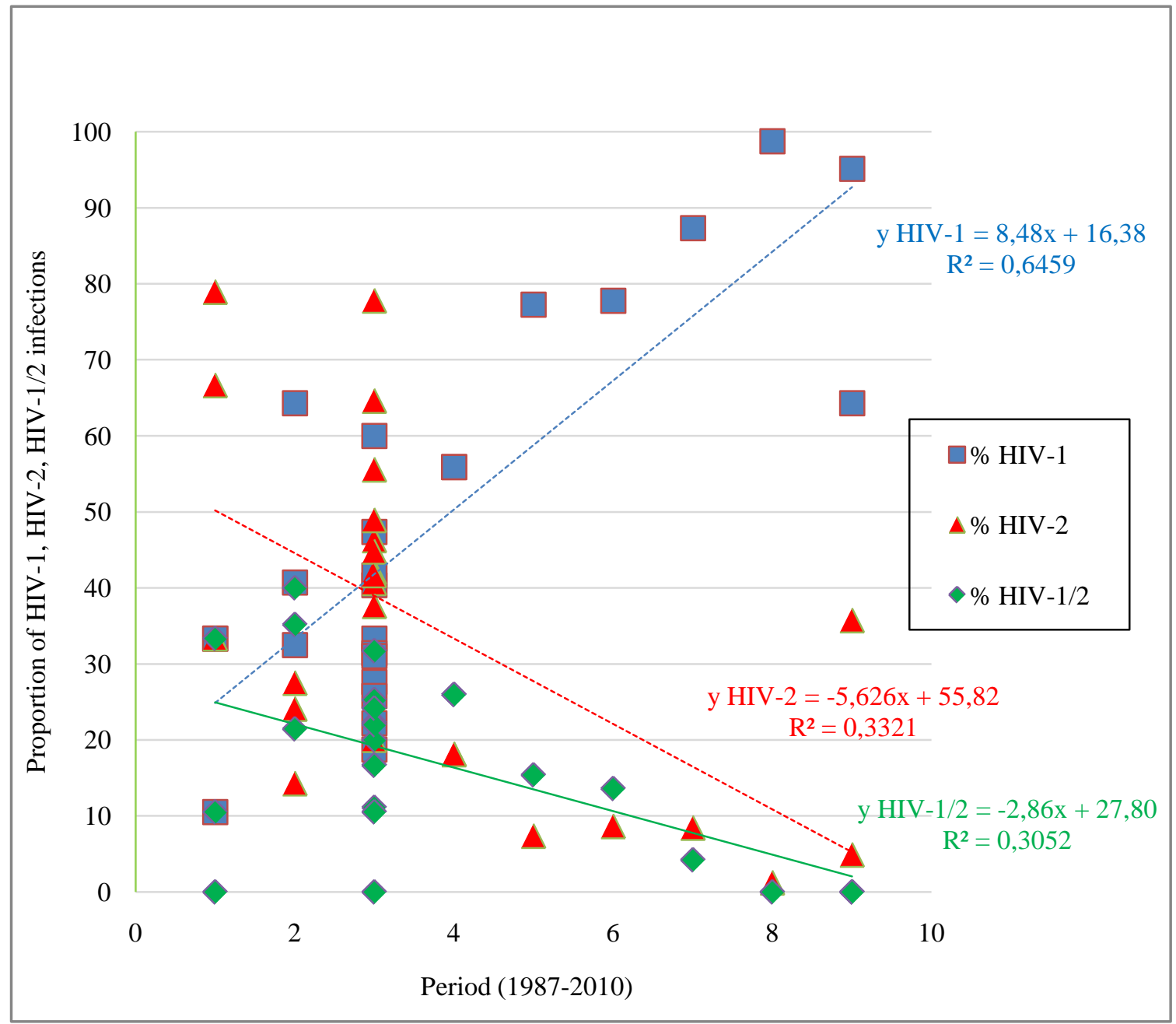

Figure 1: The trends of HIV infectious profiles in full populations studied (field Mali) in space and time 


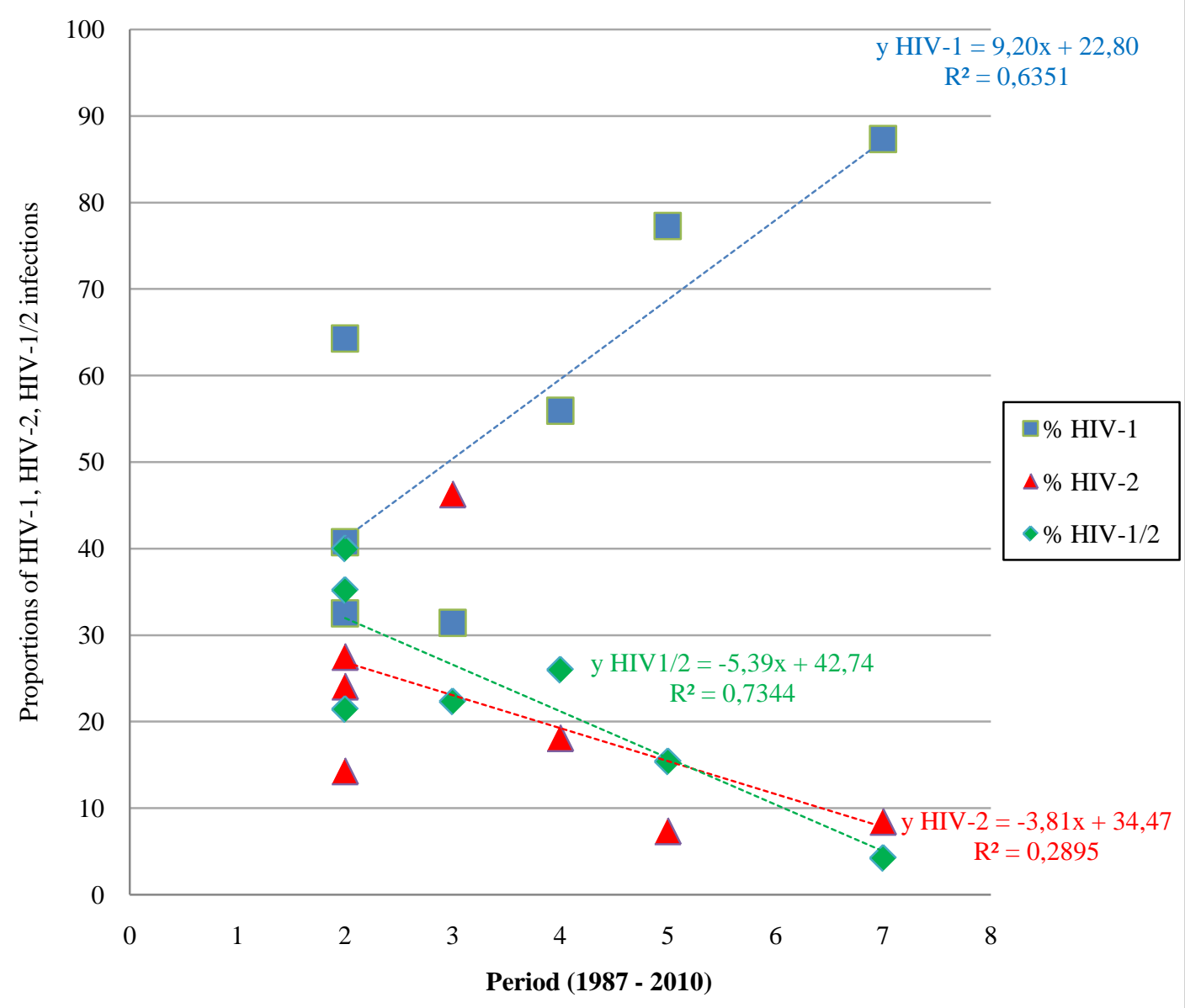

Figure 2: The trends of HIV infectious profiles in sick patients (field Mali) in space and time 